\title{
ACCOMMODATION IN THE HOLMES-ADIE SYNDROME
}

\author{
BY \\ G. F. M. RUSSELL \\ From the Neurological Research Unit, the National Hospital, Queen Square, London
}

In 1936, Bramwell suggested that the title "Holmes-Adie syndrome" be given to the clinical complex of a slowly reacting pupil and absent tendon reflexes in recognition of the descriptions by Holmes (1931) and Adie (1932). Both authors had emphasized the chief clinical features-dilatation of the pupil, apparent loss of the reaction to light, slow constriction and relaxation in response to near and distant vision, and partial loss of the tendon reflexes. Although the syndrome had been recognized wholly or in part many years previously (Strasburger, 1902; Saenger, 1902; Nonne, 1902; Markus, 1906; Weill and Reys, 1926), credit must go to Adie for stressing the benign nature of the disorder and distinguishing it clearly from neurosyphilis.

In addition to the various abnormalities of the pupil, disturbances of accommodation have been described in the Holmes-Adie syndrome; Kyrieleis (1951) stated that they occurred in more than $20 \%$ of cases and Graveson (1949) found them in 16 out of 22 affected eyes. Little attention has been paid to the mechanism of the abnormality of accommodation. This paper reports the investigation of disordered accommodation in 15 patients in whom the Holmes-Adie syndrome had been present for 14 months or longer. A comparison is made between the abnormality of accommodation and that of the pupil. In view of the intimate anatomical and physiological relationships between the iris and the ciliary muscle, it is reasonable to look for similar disturbances of function as a result of disease.

A short review of our knowledge of the pupillary abnormality in the Holmes-Adie syndrome will serve as a basis for comparison. The Holmes-Adie pupil has a definite evolution. There is often an early stage of internal ophthalmoplegia when the pupil is fixed to both light and convergence; after an interval of weeks or months there follows the later stage in which the typical Holmes-Adie pupil develops its tonic reaction (Rothmann, 1903; Axenfeld, 1919; Reitsch, 1925; Alajouanine and Morax, 1938). By the term "tonic reaction" is generally meant the slowness of pupillary constriction and the even slower pupillary dilatation in

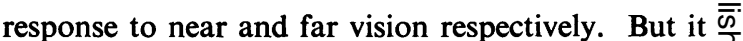
has also been noted that the reaction to convergence $\stackrel{\mathbb{D}}{\square}$ may be remarkably wide in its range, considering that it often follows a stage of complete paralysis (Strasburger, 1902). Not only is the reaction to ? convergence well preserved when compared to the $\overrightarrow{\vec{\omega}}$ reaction to light, but it may in fact be excessive $\stackrel{\sigma}{\omega}$ (Alajouanine and Morax, 1938; Heersema and Moersch, 1939). In assessing the degree of tonicity there are, therefore, two criteria: slowness of $\underset{\sim}{N}$ pupillary movement and preservation of the range of movement.

Adler and Scheie (1940) showed that the ton pupil constricts after the conjunctival instillatiog of the weak parasympathomimetic drug acetyl-1 methylcholine, in concentrations which have effect on normal pupils. Scheie (1940) accounted for $\Phi$ the slow constriction during convergence of the eyes by a similar sensitivity of the sphincter pupillae to acetylcholine released by any surviving paras $\overrightarrow{0}$ sympathetic fibres. He explained the slowness of 1 relaxation as the delay required for the destruction of acetylcholine by cholinesterase. This hypothesis of hypersensitivity of the partially denervated sphincter pupillae is in accordance with the law of denervation put forward by Cannon and Rosenblueth (1949) who stated that, when a chain of $\stackrel{\mathbb{Q}}{2}$ neurons is severed, there results after an interval a $\overrightarrow{\overrightarrow{0}}$ hypersensitivity of the distal elements and effectors to 3 the action of nerve impulses, and to certain chemical agents either injected parenterally or applied locally.

A paralysis or weakness of accommodation often results as part of the internal ophthalmoplegia which may be the early stage of the syndrome. During the later stage, when the fixed pupil changes 3 into a tonic one, there is an accompanying improve- $\delta$ ment in accommodation (Holmes, 1931; van Leeu- 3 wen, 1946). From the clinical standpoint, the early 응 stage may be manifested by blurring of vision; the patient is unable to read small print with the affected o eye owing to recession of the near point. During the later stage, the range of accommodation is restored, $\sigma$ with improvement of vision, but there often remains $N$ a slight disability - accommodation may be delayed N 
before either the near or the distant object is seen clearly. As in the case of the slow pupillary constriction, slow accommodation has been termed tonic. Graveson (1949) reported tonic accommodation for near vision in the majority of his patients. However, other authors found that the greater delay in accommodation occurs for far vision (Markus, 1906; Reitsch, 1925; Holmes, 1931; Adie, 1932; Heersema and Moersch, 1939); the patient is unable to relax accommodation when looking from a close to a distant object. This symptom has been termed spasm of accommodation; it can also be induced in normal subjects by instilling powerful parasympathomimetic drugs into the conjunctival sac. It has already been mentioned that there is an increase in the sensitivity of the tonic pupil to the drug acetyl-B-methylcholine. These two facts suggest the possibility of an increased sensitivity of the ciliary muscle to parasympathomimetic drugs.

In the Holmes-Adie syndrome the defect of accommodation appears to follow the same sequence as that of the pupil: paralysis followed by a tonic reaction. It was considered worthwhile verifying this supposition and the following questions were therefore asked:-

(1) Is there a recovery in the range of accommodation by the time the tonic pupil has developed ?

(2) Is there a delay in accommodation ?

(3) Is the affected ciliary muscle more sensitive to parasympathomimetic drugs ?

Material

Accommodation was examined in 15 patients with the
Holmes-Adie syndrome. Table I shows details of their age, sex, pupillary abnormalities, and tendon reflexes. In every patient the blood Wassermann reaction was negative; in six patients (Cases 2, 3, 4, 9, 13, and 15), on whom a lumbar puncture was performed, the Wassermann reaction in the cerebrospinal fluid was likewise negative. Among these patients 20 eyes were selected for examination, using two criteria: (a) Each eye had to show a well-established tonic pupil. The severity of the pupillary abnormality was judged by the abolition or severe impairment of the light reflex. (b) A sufficient interval of time had to elapse after the onset of the disorder (14 months or longer). This interval would permit the development of tonic accommodation if such a change were going to occur.

It was considered essential to compare the eyes of the Holmes-Adie patients with the eyes of normal subjects, and to match each patient with a normal subject for age and sex. It is well known that normal accommodation diminishes with age. Owing mainly to sclerotic changes in the crystalline lens, accommodation decreases from birth onwards, until it is lost around the age of 50 to 60 ; different ages are quoted for the total loss of accommodation, according to the authority and the method of measurement (Hamasaki, Ong, and Marg, 1956). Furthermore, for any given age, there is a physiological range of up to 4 dioptres for normal accommodation (Duane, 1925). A particular effort was made to obtain a close agreement in age; the age in years of the normal control agreed exactly with that of the patient in 11 cases, and within a year in four cases (Table II). Care was also taken not to include as a normal control any subject with a severe refractive error. Where the abnormality was bilateral, both eyes of the control were tested: where it was unilateral, only the corresponding eye was examined.

TABLE $\mathbf{i}$

CLINICAL FINDINGS IN FIFTEEN PATIENTS WITH HOLMES-ADIE SYNDROME

\begin{tabular}{|c|c|c|c|c|c|}
\hline Case & Age & Sex & History & Clinical Features & Tendon Reflexes \\
\hline$\frac{1}{2}$ & $\begin{array}{l}57 \\
56\end{array}$ & $\begin{array}{l}\mathrm{F} \\
\mathrm{F}\end{array}$ & Blurred vision (1924) & $\begin{array}{l}\text { Oval tonic left pupil } \\
\text { Bilateral irregular tonic pupils }\end{array}$ & $\begin{array}{l}\text { Absent T.J.s, K.J.s, and A.J.s } \\
\text { All absent }\end{array}$ \\
\hline 3 & 53 & $\mathbf{M}$ & Incidental finding (1955); glare & $\begin{array}{l}\text { Oval tonic pupil, ptosis and facial anhidrosis } \\
\text { on the left }\end{array}$ & A.J.s sluggish \\
\hline 4 & 49 & $\mathbf{M}$ & Incidental finding (1955) & tonic pupil and slow accommoda- & Absent A.J.s \\
\hline 5 & 43 & $\mathbf{M}$ & $\begin{array}{l}\text { Sudden blurred and double vision } \\
(1956)\end{array}$ & $\begin{array}{l}\text { Bilateral irregular tonic pupils and slow } \\
\text { accommodation }\end{array}$ & Normal \\
\hline 6 & 42 & $\mathbf{M}$ & $\begin{array}{l}\text { Delayed accommodation and unequal } \\
\text { pupils (1951) }\end{array}$ & $\begin{array}{l}\text { Bilateral irregular tonic pupils and slow } \\
\text { accommodation }\end{array}$ & Absent A.J.s \\
\hline $\begin{array}{l}7 \\
8\end{array}$ & $\begin{array}{l}38 \\
38\end{array}$ & $\begin{array}{l}\mathbf{F} \\
\mathbf{F}\end{array}$ & $\begin{array}{l}\text { Incidental finding (1956). Delayed } \\
\text { accommodation } \\
\text { Incidental finding (1954) }\end{array}$ & $\begin{array}{l}\text { Bilateral irregular tonic pupils and slow } \\
\text { accommodation } \\
\text { Irregular tonic left pupil; normal accommo- }\end{array}$ & $\begin{array}{l}\text { Absent B.J.s, T.J.s, K.J.s, and } \\
\text { A.J.s } \\
\text { All absent }\end{array}$ \\
\hline 9 & 37 & $\mathbf{F}$ & Incidental finding (1955 & $\begin{array}{l}\text { dation irregular tonic pupils: no } \\
\text { Bilateral irregulan } \\
\text { accommodation }\end{array}$ & $\begin{array}{l}\text { Absent K.J.s, A.J.s, and right } \\
\text { B.J. and S.J. }\end{array}$ \\
\hline 10 & 37 & $\mathbf{F}$ & Sudden blurred vision (1954) & $\begin{array}{l}\text { Irregular tonic pupil with slow accommoda- } \\
\text { tion on the right }\end{array}$ & Right K.J. and left A.J. sluggish \\
\hline 11 & 36 & $\mathbf{M}$ & $\begin{array}{l}\text { Sudden blurred and double vision; } \\
\text { glare (1954) }\end{array}$ & $\begin{array}{l}\text { Fixed left pupil; tonic pupil, and slow } \\
\text { accommodation one year later }\end{array}$ & $\begin{array}{c}\text { Absent S.J.s and A.J.s; K.J.s } \\
\text { sluggish }\end{array}$ \\
\hline 12 & 35 & $\mathbf{F}$ & tal finding (1955) & $\begin{array}{l}\text { Bilateral irregular tonic pupils and slow } \\
\text { accommodation on left }\end{array}$ & Absent T.J.s, K.J.s, and A.J.s \\
\hline 13 & 26 & $\mathbf{F}$ & $\begin{array}{l}\text { Sudden blurred vision on the left } \\
\text { (1954) and on the right (1955). } \\
\text { Double vision and headaches }\end{array}$ & $\begin{array}{l}\text { Bilateral changes affecting both pupil and } \\
\text { accommodation-paralytic on the right } \\
\text { and tonic on the left }\end{array}$ & All absent except right B.J. \\
\hline 14 & 22 & $\mathbf{M}$ & $\begin{array}{l}\text { Delayed accommodation and unequal } \\
\text { pupils (1954) }\end{array}$ & $\begin{array}{l}\text { Bilateral irregular tonic pupils and slow } \\
\text { accommodation }\end{array}$ & ssent except B.J.s \\
\hline 15 & 21 & F & $\begin{array}{l}\text { Sudden ocular pain on the right; } \\
\text { enlarged left pupil noted (1955) }\end{array}$ & $\begin{array}{l}\text { Bilateral irregular tonic pupils; normal } \\
\text { accommodation }\end{array}$ & Absent K.J.s and A.J.s \\
\hline
\end{tabular}


TABLE II

DATA OF HOLMES-ADIE PATIENTS AND MATCHED NORMAL SUBJECTS

\begin{tabular}{|c|c|c|c|c|c|c|c|c|c|c|c|c|}
\hline \multirow[b]{2}{*}{ Case } & \multirow[b]{2}{*}{ Age } & \multirow[b]{2}{*}{ Sex } & \multirow[b]{2}{*}{ Side } & \multicolumn{2}{|c|}{ Refraction (dioptres) } & \multicolumn{3}{|c|}{$\begin{array}{l}\text { Range of Accommodation } \\
\text { (dioptres) }\end{array}$} & \multicolumn{3}{|c|}{$\begin{array}{l}\text { Spasm of Accommodation caused } \\
\text { by Pilocarpine (dioptres) }\end{array}$} & \multirow{2}{*}{$\begin{array}{c}\text { Constriction } \\
\text { of Pupil } \\
\text { caused by } \\
\text { Pilocarpine(mm.) } \\
\text { in Holmes-Adie } \\
\text { Subjects }\end{array}$} \\
\hline & & & & $\begin{array}{l}\text { Holmes-Adie } \\
\text { (1) }\end{array}$ & $\begin{array}{c}\text { Normal } \\
(2)\end{array}$ & $\begin{array}{l}\text { Holmes-Adie } \\
\text { (3) }\end{array}$ & $\begin{array}{l}\text { Normal } \\
\text { (4) }\end{array}$ & $\begin{array}{l}\text { Difference } \\
\text { between } \\
\text { (3) and (4) }\end{array}$ & Holmes-Adie & $\begin{array}{c}\text { Normal } \\
\text { (6) }\end{array}$ & $\begin{array}{l}\text { Difference } \\
\text { between } \\
\text { (5) and (6) }\end{array}$ & \\
\hline 1 & 57 & $\mathbf{F}$ & $\mathbf{L}$ & +0.9 & +1.4 & 0 & 0 & 0 & 0.7 & 0 & +0.7 & 27 \\
\hline 2 & 56 & $\mathbf{F}$ & $\mathbf{R}$ & $\begin{array}{l}+3 \cdot 8 \\
+3.2\end{array}$ & $\begin{array}{l}+1 \cdot 2 \\
+1.2\end{array}$ & $\begin{array}{l}0 \\
0\end{array}$ & 0 & 0 & $1 \cdot 2$ & 0 & +1.2 & 4 \\
\hline 3 & 53 & $\mathbf{M}$ & $\mathbf{L}$ & $\begin{array}{r}+3.2 \\
-0.1\end{array}$ & $\begin{array}{r}+1.2 \\
-1.2\end{array}$ & $\begin{array}{l}0 \\
0\end{array}$ & $\begin{array}{l}0 \\
0\end{array}$ & $\begin{array}{l}0 \\
0\end{array}$ & $\begin{array}{l}0 \cdot 4 \\
0\end{array}$ & $\begin{array}{l}0 \\
0\end{array}$ & $\begin{array}{l}0 \cdot 4 \\
0\end{array}$ & $3 \frac{1}{2}$ \\
\hline 4 & 49 & $\mathbf{M}$ & $\mathbf{R}$ & +0.7 & +1.5 & 0 & 0.3 & -0.3 & $2 \cdot 0$ & 0.5 & $\begin{array}{r}0 \\
+1.5\end{array}$ & $\overline{4 \frac{1}{2}}$ \\
\hline 5 & 43 & $\mathbf{M}$ & $\mathbf{L}$ & +0.7 & +2.4 & $1 \cdot 1$ & $3 \cdot 1$ & -2.0 & $1 \cdot 2$ & 0.1 & $+1 \cdot 1$ & $2^{2}$ \\
\hline 6 & 42 & $\mathbf{M}$ & $\mathbf{R}$ & -1.4 & $+2 \cdot 3$ & $1 \cdot 0$ & $2 \cdot 5$ & $-1 \cdot 5$ & $0 . \overline{4}$ & 0 & +0.4 & 2 \\
\hline 7 & 38 & $\mathbf{F}$ & $\mathbf{R}$ & +0.3 & -0.5 & $5 \cdot 1$ & 1.5 & $+3 \cdot 6$ & 2 . & 1.0 & +1.6 & 2 \\
\hline & & & L & 0.0 & +0.1 & $3 \cdot 3$ & $2 \cdot 0$ & $+1 \cdot 3$ & $2 \cdot 0$ & $1 \cdot 7$ & $+0 \cdot 3$ & 3 \\
\hline 8 & 38 & $\mathbf{F}$ & L & $+1 \cdot 1$ & -0.3 & $2 \cdot 8$ & $1 \cdot 5$ & $+1 \cdot 3$ & 2 . & 0.6 & +1.9 & 24 \\
\hline 9 & 37 & $\mathbf{F}$ & $\begin{array}{l}\mathbf{R} \\
\mathbf{L}\end{array}$ & $\begin{array}{r}0.0 \\
+1.3\end{array}$ & $\begin{array}{l}-0 \cdot 1 \\
+0.1\end{array}$ & $\begin{array}{l}5 \cdot 1 \\
2 \cdot 2\end{array}$ & $\begin{array}{l}6 \cdot 7 \\
6 \cdot 5\end{array}$ & $\begin{array}{l}-1 \cdot 6 \\
-4 \cdot 3\end{array}$ & $\begin{array}{l}0 \cdot \\
1 \cdot\end{array}$ & $\begin{array}{l}1 \cdot 8 \\
1 \cdot 1\end{array}$ & $\begin{array}{l}-1 \cdot 0 \\
-0 \cdot 1\end{array}$ & $\begin{array}{l}1 \frac{1}{2} \\
2 \frac{3}{2}\end{array}$ \\
\hline 10 & 37 & $\mathbf{F}$ & $\mathbf{R}$ & +0.2 & -1.7 & $4 \cdot 6$ & $5 \cdot 3$ & -0.7 & 0.1 & $3 \cdot 1$ & $-3 \cdot 0$ & $1 \frac{4}{2}$ \\
\hline 11 & 36 & $\mathbf{M}$ & L & $-2 \cdot 7$ & +0.3 & $5 \cdot 2$ & $4 \cdot 2$ & $+1 \cdot 0$ & $4 \cdot 3$ & 0.5 & +3.8 & $3 \frac{1}{2}$ \\
\hline 12 & 35 & $\mathbf{F}$ & L & +3.9 & 0.6 & $2 \cdot 3$ & $5 \cdot 4$ & $-3 \cdot 1$ & $0 \cdot 3$ & $0 \cdot 3$ & 0 & 1 \\
\hline 13 & 26 & $\mathbf{F}$ & $\mathrm{R}$ & $\begin{array}{l}0.5 \\
0.7\end{array}$ & $\begin{array}{l}-0.7 \\
-0.8\end{array}$ & $\begin{array}{l}6 \cdot 2 \\
7 \cdot 2\end{array}$ & $\begin{array}{l}8 \cdot 7 \\
9 \cdot 1\end{array}$ & $\begin{array}{r}-2.5 \\
-1.9\end{array}$ & $\begin{array}{l}4 \cdot 2 \\
0 \cdot 3\end{array}$ & $\begin{array}{l}0.7 \\
1.0\end{array}$ & $\begin{array}{r}+3 \cdot 5 \\
-0.7\end{array}$ & $3 \frac{1}{2}$ \\
\hline 14 & 22 & $\mathbf{M}$ & $\mathbf{R}$ & -0.3 & -0.2 & - & - & -19 & $5 \cdot 5$ & $\begin{array}{l}1.0 \\
1.4\end{array}$ & +4.1 & $\begin{array}{l}52 \\
5 \frac{1}{2}\end{array}$ \\
\hline & & & $\mathbf{L}$ & $-2 \cdot 8$ & $-0 . \overline{3}$ & - & - & - & $4 \cdot 8$ & $2 \cdot 8$ & & 4 \\
\hline 15 & 21 & $\mathbf{F}$ & $\mathbf{L}$ & -0.4 & +0.3 & $5 \cdot 1$ & $7 \cdot 7$ & $-2 \cdot 6$ & 0.6 & 0 & +0.6 & $2 \frac{1}{2}$ \\
\hline
\end{tabular}

\section{Methods}

(1) Measurement of Accommodation.-Accommodation was measured by the difference in refraction of the eye caused by accommodating from distant to near vision. A modification of the coincidence optometer designed by Fincham (1937) was used, both for refracting the eye and for providing the stimulus to accommodation. The refraction of the eye was measured objectively by viewing ophthalmoscopically the retinal image of an illuminated target consisting of a vertical line (Fig. 1). When the eye examined was ametropic, the retinal image fell to one or other side of the principal axis of the eye. This displacement could be seen through the observing system and corrected by altering the position of the targeto relative to an optometer lens. The required correction represented the refractive error which was read in 음 dioptres on the scale carrying the moving target. The adjustment was made with precision by a coincidence setting. The accommodation stimulus was provided by $q$ second fixation target illuminated by a beam of light

FIG. 1.-This diagram illustrates the principle of the coincidence optometer. $T$ is a linear target illuminated by a 36-watt lamp, $S$. The beam of light enters the pupil at a fixed distance from the principal axis $F F^{\prime}$. The image of $T$ is projected on the subject's retina at $T^{\prime}$. In the diagram, $T^{\prime}$ is slightly displaced from the principal axis. The reflected beam of light emerges from the eye and is intercepted by the prism, $P$, which reverses half the retinal image to an equal distance on the opposite side of the principal axis. If the subject's eye is ametropic (as when accommodating for near vision), therefore, the observer will detect a separation of the two halves of the retinal image ( $T^{\prime}$ and $T^{\prime}{ }_{2}$ ). The observer will then adjust the position of $T, e . g$. to $x$, until the two halves of the image coincide. The required adjustment $T$ gives a measure of the refractive error (or refraction of the accommodated eye).
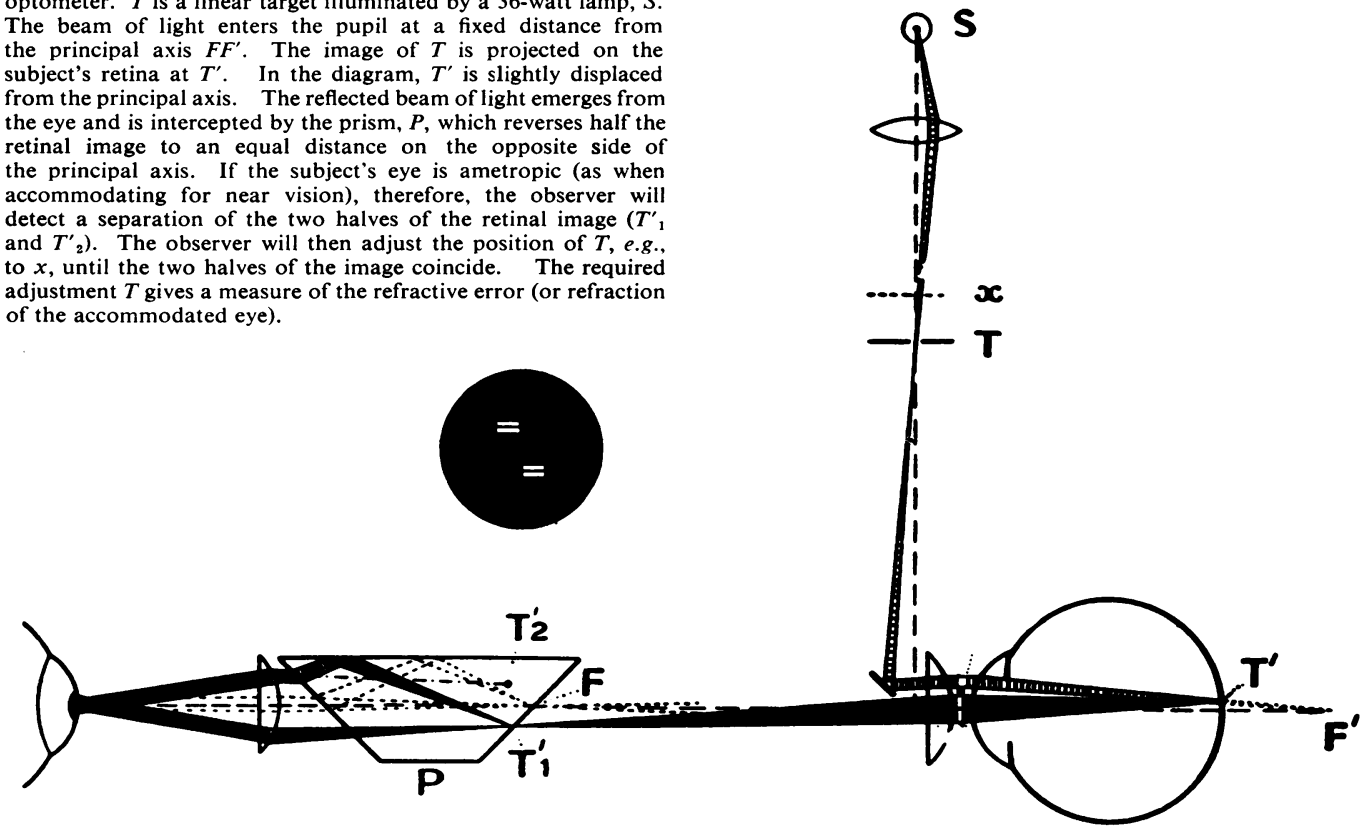
the vergence of which could be varied. When the light proceeding from the target was parallel, accommodation was relaxed; increasing divergence of light caused a corresponding increase in accommodation. This response is thought to depend on changes in chromatic aberration and on the normal scanning movements of the eye (Fincham, 1951). The fixation target consisted of a detailed black and white pattern which provided a good stimulus to accommodation (Fincham and Walton, 1957). To avoid errors from spherical aberration and from astigmatism, the instrument was centred on the pupil and the same meridian was used before each measurement. Alterations in size of the pupil are likely to cause changes of accommodation by themselves if there result any differences of light vergence. To overcome this important difficulty, the beam of light from the illuminating system was made to enter the pupil at a fixed distance from its centre; a constancy of size $\left(2 \frac{1}{2} \mathrm{~mm}\right.$. diameter) of the " effective pupil" was thus ensured. A high degree of consistency was attained with this instrument; in a series of four normal subjects, on each of whom the refraction of the relaxed eye was measured on four consecutive days, the standard deviation was $0 \cdot 14$ dioptre.

In order to decide if accommodation was significantly reduced in the Holmes-Adie patients, values were obtained for 18 eyes among 14 patients and compared with those of 18 normal eyes. One patient (Case 14) had an amblyopic left eye and the coincidence optometer did not provide an adequate stimulus to accommodation; he was therefore omitted from the investigation.

(2) Timing of Accommodation.--It was not possible to time accommodation with the coincidence optometer, for even normal subjects sometimes failed to respond for several seconds to the stimulus of rapidly altering vergence of light. The delay in accommodating for near or distant vision was also influenced by practice, so that consistent observations were not obtainable.

Graveson's (1949) clinical method was therefore used for measuring the delay in accommodation for near vision in the Holmes-Adie patients. A Jaeger test card which could be read comfortably at a distance greater than the near point was chosen (usually J4 to J8). The patient was asked to change his gaze from a distant object to the Jaeger card, which he held in his hand, and the interval before he could see the print clearly was timed with a stop watch. In a normal subject there is no significant delay.

Estimations were restricted to 11 patients under the age of 45 , because presbyopic changes in older patients made timing inaccurate. Among these patients, 16 eyes with tonic pupils were examined.

(3) Response of Accommodation to Pilocarpine.Accommodation was measured with the coincidence optometer. Two drops of $1 \%$ pilocarpine nitrate were then instilled from a pipette into the eye, which was later re-examined at five-minute intervals until the maximum effect of the drug was observed. This usually took from 20 to 30 minutes. Fig. 2 shows the effect of this test on a normal subject; for any given strength of accommodative stimulus, there tended to be an enhanced accommodative response after the administration of pilocarpine.
This is in agreement with the findings of Fincham (1955), who used eserine instead of pilocarpine. Another feature of the reaction to pilocarpine was an inability of the ciliary muscle to relax fully, as shown by a more myopic reading ( $\mathrm{X}$ instead of $\mathrm{Y}$ in Fig. 2) when the accommodative stimulus was withdrawn. This inability to relax accommodation, or spasm of accommodation, was chosen as a measure of the effect of pilocarpine on the ciliary muscle, and is represented in Fig. 2 by the distance XY (expressed in dioptres).

The effect of pilocarpine was tested in 20 eyes with tonic pupils among 15 Holmes-Adie patients. The induced spasm of accommodation was determined in each abnormal eye and compared with $(a)$ the spasm of accommodation in the normal control eye, and $(b)$ the response to pilocarpine of the tonic pupil of the same eye. This response was measured by the difference between the pupillary diameters (in $\mathrm{mm}$.) before and after treatment with the drug. The measurement of the pupil was obtained at the same time as accommodation was tested, using a simple Haab pupillometer.

\section{Results}

Measurement of Accommodation.-Table II shows how the range of accommodation in the HolmesAdie patients (column 3) differed from that in the normal controls (column 4). The differences between the two groups are also shown; a negative sign indicates that accommodation was less in the abnormal eye. The means between the abnormal and control groups were compared by a $t$ test (for correlated means). The range of accommodation for the Holmes-Adie group was found to be slightly reduced in comparison with that of the normal group, but this difference was found to be not significant $(P=>0.05)$.

Timing of Accommodation.-Accommodation for near vision was found to be delayed in 13 out of the 16 eyes examined. The time lag varied from three to 13 seconds (Table III).

TABLE III

DELAY IN ACCOMMODATION FOR NEAR VISION

\begin{tabular}{c|c|c}
\hline Case & Side & Delay in Accommodation for \\
Near Vision (sec.)
\end{tabular}




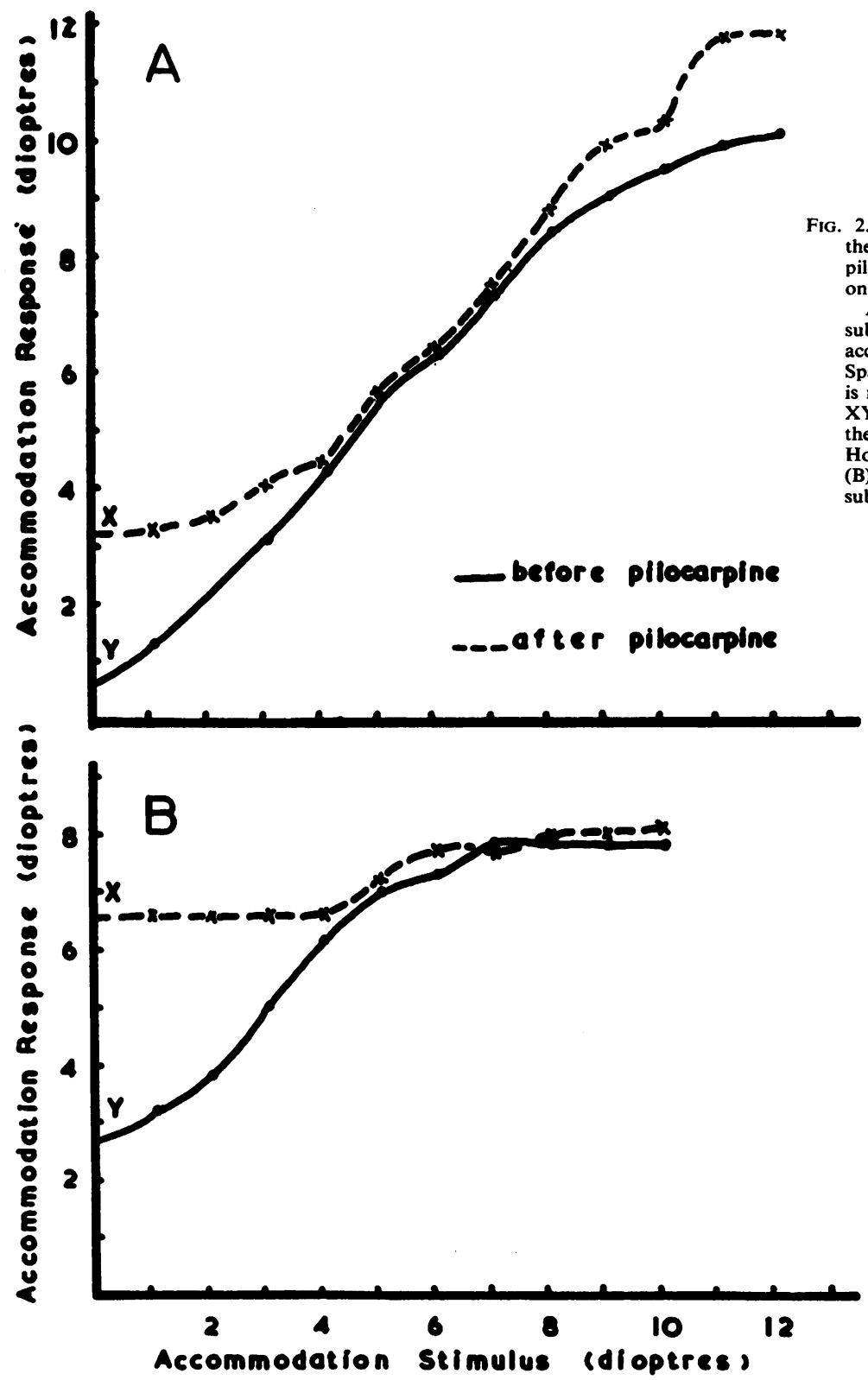

. 2.-Diagram illustrating the effect of instillation of pilocarpine nitrate $(1 \%)$ ज on accommodation.

After pilocarpine, the $\bar{O}$ subject is unable to relax $\frac{\bar{\sigma}}{\sigma}$ accommodation fully. $\frac{\overline{\bar{C}}}{\bar{T}}$ Spasm of accommodation $\bar{\sigma}$ is represented by distance $\overparen{D}$ $X Y$ which is greater in the patient with the

Holmes-Adie syndrome

(B) than in the normal $\overrightarrow{0}$ subject (A).

Response of Accommodation to Pilocarpine.Table II shows how the accommodation of HolmesAdie patients differed in its response to pilocarpine from that of normal subjects: a positive sign indicates that the spasm of accommodation was greater in the abnormal eye. The means between the Holmes-Adie and control group were compared by a $t$ test (for correlated means). The spasm of accommodation for the Holmes-Adie group was found to be significantly increased in comparison with the normal group $(P=<0.05)$.

A correlation was sought between the effect of $\frac{D}{0}$ pilocarpine on accommodation and on the size of the tonic pupil of the same abnormal eye (Table II). $/$ A correlation coefficient of +0.59 , significant at the $N$ $1 \%$ level, was obtained. This indicates that the N 
sensitivity of the ciliary muscle to pilocarpine tends to increase with that of the sphincter pupillae in the Holmes-Adie syndrome.

\section{Discussion}

Fifteen patients with tonic pupils of long standing were examined for remaining signs of abnormal accommodation. It was confirmed that a considerable recovery takes place in the range of accommodation; in fact, no significant difference could be detected between the Holmes-Adie group and the normal controls. In many patients a delay of accommodation develops, which is the defect most easily detected by clinical methods. The group of Holmes-Adie eyes showed a significant increase in sensitivity of the ciliary muscle to pilocarpine. The disturbance of accommodation therefore undergoes a series of changes strictly analogous to those of the tonic pupil; the ciliary muscle eventually recovers its ability to contract and the movement of contraction becomes slower. The ciliary muscle also develops a heightened sensitivity to pilocarpine. This increase in sensitivity bears some relationship to that of the iris. There is good evidence, therefore, for supposing that the abnormal processes affecting the pupil and accommodation are identical. Furthermore, just as the tonic pupil is often preceded by a paralytic one, it is likely that tonic (delayed) accommodation supervenes on a paralysis of accommodation.

It does not follow that every patient with the Holmes-Adie syndrome has at some time had a paralysis of accommodation. In many cases no symptoms are ever noticed, though close enquiry will often elicit the history of a forgotten episode of blurred vision. The development of symptoms depends a great deal on how much the patient relies on his accommodative power. This reliance on accommodation is lessened in myopia and absent in presbyopia, so that myopic and middle-aged subjects may not become aware of abnormal accommodation. With hypermetropia or astigmatism, however, a sudden paralysis of accommodation may prove to be temporarily disabling, especially if it occurs in the young.

Because the tonic reaction is so distinctive and involves both the pupil and accommodation, the understanding of its physiopathology assumes some importance. Two main hypotheses have been formulated to account for the tonic reaction: first, a disturbance of sympathetic function; second, an increased sensitivity of the effector muscles following partial parasympathetic denervation. Evidence has been presented in favour of discarding the first hypothesis (Russell, 1956): neither a lesion nor an overaction of the sympathetic innervation is present. It was shown, on the other hand, that the reaction to pilocarpine is increased in pupils showing the tonic reaction; indeed, the sensitivity to pilocarpine bears a direct relationship to the range of movement caused by convergence, and to the time taken by the pupil to dilate again. Moreover, it was argued that in the tonic pupil parasympathetic function is partly preserved. These facts substantiate the theory put forward by Scheie (1940) that the tonic reaction is due to surviving parasympathetic fibres releasing acetylcholine which diffuses to neighbouring denervated, and therefore sensitized, muscle fibres. Is there any difference between the action of acetylcholine released at nerve endings and that of a parasympathomimetic drug applied locally, as in this investigation ? There would not appear to be, for experimental denervation of the iris results in hypersensitivity to all parasympathomimetic substances, including acetylcholine, whether these substances be injected parenterally or instilled in the conjunctiva (Bender and Weinstein, 1940; Keil and Root, 1941 and 1942; Neidle, 1950). The effect of pilocarpine on the sphincter pupillae and ciliary muscle may be taken to mirror the action of acetylcholine under natural conditions.

The development of paralysis of the pupil and of accommodation with subsequent hypersensitivity to parasympathomimetic drugs places the site of the lesion along the parasympathetic pathway between the third nerve nucleus and the short ciliary nerve endings. It remains uncertain whether the pre- or post-ganglionic nerves are primarily affected, but the evidence favours a post-ganglionic lesion. Thus, there are clinical records of tonic pupils developing after injuries or tumours established as affecting the ciliary ganglion or short ciliary nerves (Axenfeld, 1906; Ohm, 1907; Cords, 1930; Garcin and Kipfer, 1936); a single pathological examination (Ruttner, 1947) has revealed degeneration of ganglion cells in the ciliary ganglion.

There remain many gaps in our knowledge. Experimental work shows that increased sensitivity of the denervated iris develops within a few hours, whereas a much longer period may elapse before the same phenomenon develops after an internal ophthalmoplegia in the human. In one patient observed the tonic reaction of the pupil became manifest only about three months after increased sensitivity to pilocarpine had been detected. An explanation is suggested by the work of Murray and Thompson (1957). They showed that recovery of function after partial sympathectomy in cats depends, not on hypersensitivity, but on collateral sprouting of the surviving sympathetic fibres. By the end of four to eight weeks, the sprouts form new synapses with the denervated ganglion or 
effector cells. The phenomenon has not been demonstrated yet in the parasympathetic system, but if it were, it would account more readily for the delay in recovery of pupillary constriction and of accommodation. The tonic reaction would therefore result from two combined sequels to a parasympathetic lesion-hypersensitivity of the effector cells and formation of new connexions by sprouting.

\section{Summary}

Accommodation was studied in 15 patients with the Holmes-Adie syndrome in whom ocular abnormalities had been present for 14 months or longer. A coincidence optometer was used to measure the range of accommodation and spasm of accommodation induced by instilling pilocarpine in the conjunctival sac. The delay in accommodating for near vision was measured by simple clinical means. It was found that the disorder of accommodation is very similar to that of the pupil: there is a recovery in accommodative power but contraction of the ciliary muscle is delayed and there develops a sensitivity to the action of pilocarpine. Moreoever, there is a significant correlation between the sensitivity of the ciliary muscle and that of the sphincter pupillae. It is argued that the tonic reaction of the pupil and of accommodation must have a similar mechanism which may be dependent partly on the development of sensitivity of the denervated effector muscle to acetylcholine.

I wish to thank Dr. E. A. Carmichael for his encouragement and for providing facilities to carry out this work, Mr. E. F. Fincham for valuable guidance, and Dr. A. E. Maxwell for statistical advice. I am also grateful to

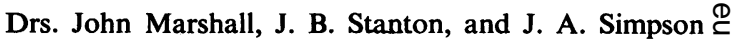
for allowing me to examine patients under their care. Fig. 1 is reproduced by kind permission of Stearman Optical Company Ltd. The work was carried out during $\widehat{\theta}$ the tenure of a Clinical Research Fellowship of the $D$ Medical Research Council, and was submitted in a thesis for the M.D. degree of the University of Edinburgh.

\section{REFERENCES}

Adie, W. J. (1932). Brain, 55, 98.

Adler, F. H., and Scheie, H. G. (1940). Trans. Amer. ophthal. Soc. 38, 183 . 205 and 277.

Axenfeld, T. (1906). Dtsch. med. Wschr., 32, 663.

- (1919). Klin. Mbl. Augenheilk., 62, 59.

Bender, M. B., and Weinstein, E. A. (1940). Amer. J. Physiol, (D) 130, 268.

Bramwell, (1936). Trans. med.-chir. Soc. Edinb., n.s. 50, 83.

Cannon, W. B., and Rosenblueth, A. (1949). The Supersensitivity of Denervated Structures. Macmillan, New York.

Cords, R. (1930). Zbl. ges. Neurol. Psychiat., 55, 701.

Duane, A. (1925). Arch. Ophthal. (Chicago), 54, 566.

Fincham, E. F. (1937). Proc. phys. Soc., 49, 456.

(1951). Brit. J. Ophthal., 35, 381.

(1955). J. Physiol. (Lond.), 128, 99.

_ and Walton, J. (1957). Ibid., 137, 488.

Garcin, R., and Kipfer, M. (1936). Rev. neurol., $65,128$.

Graveson, G. S. (1949). J. Neurol., Neurosurg. Psychiat., 12, 219.

Hamasaki, D., Ong, J., and Marg, E. (1956). Amer. J. Optom., î 33, 3 . Heersema, . P. H., and Moersch, F. P. (1939). Proc. Mayo Clin., i

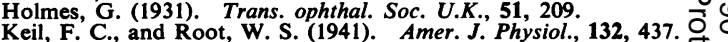
(1942). Ibid., 136, 173.

Kyrieleis, W. (1951). Pupillotonie und Adie-syndrom. Carl Marhol Halle (Saale).

Leeuwen, M. A. van (1946). Ophthalmologica (Basel), 111, 339.

Markus, C. (1906). Trans. ophthal. Soc. U.K., 26, 50. Murray, J. G., and Thompson, J. W. (1957). J. Physiol. (Lond. F,

Neidle, E. A. (1950). Amer. J. Physiol., 160, 467.

Nonne, M. (1902). Neurol. Z Zbl., 21, 1000.

Ohm, J. (1907). Zbl. prakt. Augenheilk., 31, 193.

Reitsch, W. (1925). Klin. Mbl. Augenheilk., 74, 159.

Rothmann, M. (1903). Neurol. Zbl., 22, 242 .
Russell, G. F. M. (1956). J. Neurol. Neurosurg. Psychiat., 19, 289.

Ruttner, F. (1947). Mschr. Psychiat. Neurol., 114, 265.

Saenger, A. (1902). Neurol. Zbl., 21, 837.

Scheie, H. G. (1940). Arch. Ophthal. (Chicago), 24, 225.

Strasburger, J. (1902). Areurol. Zbl., 21, 738.

Weill, G., and Reys, L. (1926). Rev. Oto-neuro-Ocul., 4, 433. 